\title{
ANALISIS ISI BUKU MATEMATIKA KURIKULUM 2013 SMP KELAS VIII SEMESTER 1 BERDASARKAN TAKSONOMI TIMSS
}

\author{
Yuyun Evi Mawarni ${ }^{(1)}$ \\ SMP Negeri 3 Simo Boyolali \\ yuyun.haryadi@gmail.com
}

DOI : 10.23917/varidika.v31vi2i.10214

\begin{abstract}
Submission
Track:

Received:

8 July 2019

Final Revision:

8 october 2019

Available online:

27 December 2019

Corresponding

Author:

Yuyun Evi

Yuyun.haryadi@gmail.com

\section{ABSTRACT}

The purpose of this research was to determine the composition of the material and practice questions in the mathematics curriculum guide 2013 junior class VIII Semester 1 in terms of content and cognitive domain taxonomy based on TIMSS. This study was a content analysis study (content analysis). The results showed that the analysis of the presentation of the material in terms of the proportion of each content domain, domain algebra occupied the highest proportion with a percentage of $50 \%$, the domain geometry with $33.33 \%$ while the percentage of domain data and opportunities with a percentage of $16.67 \%$ and there are no material including in the domain of numbers. Judging from the cognitive dimensions, applying knowing domain is $(68.42 \%)$ and knowing is $(21.05 \%)$ while the reasoning domain has the $10.53 \%$ (the lowest). For analytical presentation of questions in terms of the proportion of each dimension of the content, the material has a percentage of $60.64 \%$ algebra, geometry material has persetase $32.13 \%$ while the material data and the opportunity have a percentage of $7.23 \%$. From the cognitive dimension to training issues were gained 36 reached the level of cognitive domain knowing $16.98 \%$, 114 reached the level of cognitive domain applying with $53.77 \%$ and 62 about already reached a level of cognitive reasoning domain with $29.25 \%$.
\end{abstract}

Keywords: content analysis, the content dimension, cognitive dimension, taxonomy TIMSS.) 


\section{PENDAHULUAN}

Program pendidikan nasional diharapkan mampu melahirkan generasi dengan sumber daya manusia yang unggul dalam menghadapi tantangan jaman di masa kini dan di masa yang akan datang. Salah satu peranan pemerintah untuk memperbaiki sistem pendidikan di Indonesia yakni dengan mengadakan perubahan kurikulum. Perubahan kurikulum 2006 KTSP (Kurikulum Tingkat Satuan Pendidikan) menjadi kurikulum 2013 diharapkan mampu untuk menjawab tantangan pendidikan di era globalisasi ini. Nuh (dalam Tim Perumus, 2013: ii) mengatakan bahwa titik tekan pengembangan kurikulum 2013 adalah penyempurnaan pola pikir, penguatan tata kelola kurikulum, pendalaman dan penguasaan materi, penguatan proses pembelajaran, dan penyesuaian beban mengajar agar dapat menjamin kesesuaian antara yang diinginkan dengan yang dihasilkan.

Dalam Permendikbud (2013: 68) menyatakan bahwa kurikulum 2013 mengamanatkan esensi pendekatan ilmiah dalam pembelajaran. Pendekatan ilmiah diyakini sebagai titian emas perkembangan dan pengembangan sikap, keterampilan, dan pengetahuan peserta didik. Pendidikan ilmiah tersebut meliputi aktivitas mengamati, menanya, mencoba, mengolah, meyajikan, menyimpulkan, dan mencipta untuk semua mata pelajaran. Proses berpikir seperti itu sesuai dengan cara berpikir matematika, dimana matematika memiliki struktur dengan keterkaitan yang kuat dan jelas satu dengan yang lainnya serta pola pikir yang bersifat deduktif dan konsisten.

Namun pada kenyataannya, berdasarkan sejumlah hasil penelitian menemukan bahwa peserta didik mengalami kesulitan dalam memecahkan masalah matematika. Matematika masih menjadi momok bagi sebagian besar siswa di Indonesia. Pemahaman konsep yang masih kurang, apalagi untuk kegiatan menalar dan menghitung. Siswa cenderung kurang aktif dalam proses belajar mengajar di dalam kelas. Menurut Darhim (1993: 14) mengatakan bahwa kegunaan mata pelajaran matematika bukan hanya memberi kemampuan dalam hal perhitungan-perhitungan kuantitatif, tetapi juga dalam penataan cara berpikir, terutama dalam hal pembentukan kemampuan menganalisis, membuat sintesis, melakukan evaluasi hingga kemampuan memecahkan masalah.

Prestasi matematika peserta didik baik secara nasional maupun internasional belum menggembirakan. Data puspendik menunjukkan bahwa rata-rata nilai ujian nasional pada tingkat nasional untuk mata pelajaran matematika tahun 2015 yaitu 47,43 yang mengalami penurunan dari tahun 2014 yaitu 55,30. Peserta didik masih mengalami kesulitan pada materi statistik (penyajian data dan ukuran pemusatan data) dan materi bangun datar yang mengalami penurunan yang cukup drastis dari $72,90 \%$ menjadi $50,92 \%$.

Demikian juga dalam ajang Internasional TIMSS (Trends in International Mathematics and Science Study) yang diadakan setiap empat tahun sekali. Data dari Litbang Kemdikbud menyatakan bahwa secara signifikan prestasi siswa kelas VIII Indonesia masih jauh berada di bawah rata-rata internasional. Indonesia telah berpartisipasi sebagai peserta dari tahun 1999 sampai tahun 2011. Pencapaian prestasi matematika secara internasional terus mengalami penurunan. Pada tahun 1999 berada pada urutan 34 dari 38 negara dengan rata-rata skor 403, tahun 2003 berada pada urutan 35 dari 46 negara dengan rata-rata skor 411, tahun 2007 berada pada urutan 36 dari 49 negara dengan rata-rata skor 397 dan tahun 2011 berada pada urutan 38 dari 42 negara dengan rata-rata skor 386.

Rendahnya prestasi matematika siswa kelas VIII Indonesia pada ajang TIMSS berkaitan dengan bobot materi matematika yang diberikan pada siswa dalam pembelajaran sehari-hari. Menurut data yang diperoleh dari Permendiknas no 22 tahun 2006 tentang standar isi dinyatakan bahwa ruang lingkup mata pelajaran matematika SMP/MTs meliputi 4 aspek yaitu Bilangan, Aljabar, Geometri dan Pengukuran serta Statistika dan Peluang. Proporsi menurut 
kompetensi dasar perbandingan antara Bilangan, Aljabar, Geometri dan Pengukuran serta Statistika dan Peluang masing-masing berturut-turut adalah $16 \% ; 39 \% ; 39 \% ; 6 \%$ yang terdistribusi dari kelas VII hingga kelas IX, dengan materi statistika dan peluang berada di kelas IX, sedangkan pada kerangka kerja TIMSS 2011 untuk domain pada dimensi konten yaitu Bilangan, Aljabar, Geometri dan Pengukuran serta Data dan Peluang masing-masing berturut-turut adalah 30\%; 30\%; 20\%; 20\%. Terlihat bahwa proporsi pemberian materi matematika di Indonesia masih jauh berada dibawah proporsi TIMSS.

Untuk mengatasi masalah tersebut, pada kurikulum 2013 ini pemerintah telah menyediakan buku pelajaran untuk guru dan siswa sebagai sumber belajar. Pada buku matematika kelas VIII semester 1 kurikulum 2013 ditulis dengan berdasarkan pada materi dan kompetensi yang disesuaikan dengan standar TIMSS. Kompetensi pengetahuan bukan hanya sampai memahami secara konseptual tetapi sampai ke penerapan melalui pengetahuan dalam pemecahan masalah sehari-hari. Menurut pemerintah buku guru dan siswa tersebut telah menjabarkan usaha minimal yang harus dilakukan siswa untuk mencapai kompetensi yang diharapkan.

Permasalahannya, buku teks matematika kelas VIII yang diterbitkan pemerintah tersebut, apakah benar-benar sudah sesuai dengan kerangka pembagian kerja TIMSS 2015 dilihat dari materi pokok palajaran, soal-soal yang disajikan maupun dari aspek-aspek yang mengukur kemampuan siswa yang lain seperti pengetahuan (knowing), penerapan (applying) dan penalaran (reasoning). Oleh karena itu, buku teks harus terus semakin disempurnakan, dan harus terus direvisi agar isinya menjadi lebih baik dari tahun ke tahun maka perlu adanya penelitian lebih lanjut. Berdasarkan permasalahan tersebut maka penulis ingin melakukan analisis isi buku siswa kurikulum 2013 mata pelajaran matematika SMP kelas VIII semester 1 dikhususkan penyajiannya berdasarkan taksonomi TIMSS 2015.

\section{METODE}

Jenis penelitian ini adalah penelitian analisis isi (comntent analysis) dengan tujuan untuk menganalisis materi dan soal-soal matematika pada buku matematika kurikulum 2013 SMP kelas VIII semester 1. Teknik pengumpulan data yang digunakan dalam penelitian ini meliputi: 1) metode dokumentasi untuk pengumpulan data domain konten, domain kognitif dan aspek - aspek kognitif; 2) metode wawancara untuk mengetahui mengetahui keabsahan data yang peneliti dapatkan dari dokumentasi berdasarkan pendapat ahli.

Keabsahan data menggunakan trianggulasi metode yaitu dengan menggunakan metode dokumentasi dan wawancara. Metode dokumentasi untuk memperoleh data domain konten, domain kognitif, aspek - aspek kognitif dan pemahaman responden terhadap materi dan soalsoal pada buku siswa. Hasil analisis terhadap materi dan soal-soal pada buku siswa dilakukan pengecekkan dengan wawancara sehingga data yang diperoleh melalui masing - masing metode dapat dijadikan sebagai pembanding dan pelengkap untuk memperkuat data hasil penelitian.

Teknik analisis data yang digunakan dalam penelitian ini adalah analisis data kualitatif, meliputi: 1) mengumpulkan data domain konten, domain kognitif, dan aspek - aspek kognitif yang termuat dalam buku teks; 2) reduksi data dengan mengklasifikasikanmateri dan soalsoal berdasarkan dimensi konten, dimensi kognitif dan aspek - aspek kognitif; 3) penyajian data diarahkan agar data hasil reduksi terorganisasikan, tersusun dalam pola hubungan sehingga makin mudah dipahami. Untuk menghitung persentase tiap - tiap domain dan aspek kognitif digunakan aturan sebagai berikut: 


$$
\begin{aligned}
& (\%)=\frac{\text { Jumlah soal untuk masing-masing dimensi konten }}{\text { Jumlah soal yang dianalisis }} \times 100 \% \\
& (\%)=\frac{\text { Jumlah aspek } \text { kognitif yang sesuai kategori }}{\text { Jumlah aspek kognitif yang muncul secara keseluruhan }} \times 100 \%
\end{aligned}
$$

\section{HASIL DAN PEMBAHASAN}

Buku siswa pelajaran matematika kurikukulum 2013 SMP/MTs kelas VIII semester 1 edisi revisi yang diterbitkan oleh Kemendikbud pada tahun 2014. Materi pada buku siswa semester 1 terdiri dari 6 Bab, yaitu Bab 1 Sistem Koordinat, Bab 2 Operasi Aljabar, Bab 3 Fungsi, Bab 4 Persamaan Garis Lurus, Bab 5 Teorema Pythagoras, Bab 6 Statistika. Masingmasing Bab terdiri dari soal-soal latihan dan uji kompetensi untuk mengetahui kemampuan siswa dalam menyerap materi.

Berdasarkan hasil analisis buku siswa disesuaikan dengan taksonomi TIMSS 2015 dan temuan penelitian dari penulis, proporsi domain konten dan domain kognitif buku siswa belum sesuai dengan TIMSS 2015 Assessment Framework. Proporsi buku siswa pada materi bilangan mempunyai persentase $16 \%$, proporsi materi aljabar dan geometri mempunyai persentase yang sama sebesar 39\% sedangkan proporsi data dan peluang mempunyai persentase $6 \%$ yang terdistribusi dari kelas VII sampai kelas IX.

Menurut temuan penelitian, untuk domain konten pada materi pada buku siswa yakni bilangan tidak terdapat pada buku siswa, aljabar mempunyai persentase $50 \%$, geometri mempunyai persentase $33,33 \%$ sedangkan data dan peluang mempunyai persentase $16,67 \%$. Untuk soal-soal latihan pada buku siswa, aljabar mempunyai persentase $60,64 \%$, geometri mempunyai $32,13 \%$ sedangkan data dan peluang mempunyai persentase $7,23 \%$.

Untuk domain kognitif pada materi pada buku siswa yakni domain kognitif knowing $21,05 \%$, applying mempunyai persentase $68,47 \%$ dan reasoning mempunyai persentase $10,53 \%$. Pada soal-soal latihan pada buku siswa, domain kognitif knowing mempunyai persentase $16,98 \%$, applying mempunyai persentase $53,77 \%$ dan reasoning mempunyai persentase $29,25 \%$.

Dari hasil analisis dan temuan peneliti proporsi domain konten dan domain kognitif pada materi dan soal-soal latihan yang terdapat di dalam buku matematika kurikulum 2013 SMP kelas VIII semester 1 berdasarkan taksonomi TIMSS 2015 disajikan dalam tabel berikut:

Tabel 1. Distribusi Sebaran Domain Konten Pada Materi

\begin{tabular}{lccc}
\hline \multicolumn{1}{c}{ Domain Konten } & Buku Siswa & TIMSS 2015 & Realisasi Temuan \\
\hline Bilangan & $16 \%$ & $30 \%$ & - \\
Aljabar & $39 \%$ & $30 \%$ & $50 \%$ \\
Geometri & $39 \%$ & $20 \%$ & $33,33 \%$ \\
Data dan Peluang & $6 \%$ & $20 \%$ & $16,67 \%$ \\
\hline
\end{tabular}

Ket : Persentase buku siswa terdistribusi dari kelas VII sampai kelas IX

Tabel 2. Distribusi Sebaran Domain Kognitif Pada Materi 


\begin{tabular}{lccc}
\hline Domain Kognitif & Buku Siswa & TIMSS 2015 & Realisasi Temuan \\
\hline Knowing & - & $35 \%$ & $21,05 \%$ \\
Applying & - & $40 \%$ & $68,42 \%$ \\
Reasoning & - & $25 \%$ & $10,53 \%$
\end{tabular}

Ket : Persentase domain kognitif tidak ditetapkan oleh pemerintah

Tabel 3. Distribusi Sebaran Domain Konten pada Soal Latihan

\begin{tabular}{lccc}
\hline \multicolumn{1}{c}{ Domain Konten } & Buku Siswa & TIMSS 2015 & Realisasi Temuan \\
\hline Bilangan & $16 \%$ & $30 \%$ & - \\
Aljabar & $39 \%$ & $30 \%$ & $60,64 \%$ \\
Geometri & $39 \%$ & $20 \%$ & $32,13 \%$ \\
Data dan Peluang & $6 \%$ & $20 \%$ & $7,23 \%$ \\
\hline
\end{tabular}

Ket : Persentase buku siswa terdistribusi dari kelas VII sampai kelas IX

Tabel 4. Distribusi Sebaran Domain Kognitif pada Soal Latihan

\begin{tabular}{lccc}
\hline Domain Kognitif & Buku Siswa & TIMSS 2015 & Realisasi Temuan \\
\hline Knowing & - & $35 \%$ & $16,98 \%$ \\
Applying & - & $40 \%$ & $53,77 \%$ \\
Reasoning & - & $25 \%$ & $29,25 \%$ \\
\hline
\end{tabular}

Ket : Persentase domain kognitif tidak ditetapkan oleh pemerintah

Soal-soal yang disajikan pada bab I, II, III, IV dan VI sudah mencakup semua domain kognitif menurut TIMSS 2015 assessment framework (Mullis, et. all., 2015), akan tetapi pada Bab V tidak ditemukan soal yang hanya mencapai tingkat knowing. Keseluruhan soal pada bab V sudah mencapai tingkat kognitif applying dan reasoning.

Soal-soal dalam buku siswa matematika kurikulum 2013 kelas VIII SMP semester I terbitan Kemendikbud sebagian besar merupakan soal-soal applying yaitu soal-soal yang bersifat penerapan yang mendorong siswa untuk menyelesaikan masalah rutin. Hal ini dapat dilihat dari persentase domain applying yang selalu tertinggi di setiap Bab, terkecuali pada Bab V karena domain yang mendapat persentase tertinggi pada Bab V adalah domain kognitif reasoning.

Hasil penelitian ini juga didukung oleh penelitian Linggar Galih Mahanani (2016) tentang kemampuan pemecahan masalah matematika aljabar berbasis TIMSS pada siswa SMP kelas VIII menyimpulkan bahwa ditinjau dari domain kognitif TIMSS persentase kesalahan dalam pengetahuan (knowing) sebesar 52,8\%, penerapan (applying) sebesar $44 \%$ dan 
penalaran (reasoning) sebesar 69\% yang menunjukkan bahwa kesalahan pada memeriksa kembali dan penalaran lebih dominan dibanding dengan kesalahan lainnya.

Adapun data kandungan aspek kognitif pada masing-masing domain kognitif disajikan dalam tabel berikut :

Tabel 5. Aspek Kognitif pada masing-masing Domain Kognitif

\begin{tabular}{|c|c|c|c|c|c|c|c|c|c|}
\hline \multirow{2}{*}{$\begin{array}{l}\text { Domain } \\
\text { kognitif }\end{array}$} & \multirow{2}{*}{$\begin{array}{c}\text { Aspek } \\
\text { kognitif }\end{array}$} & \multirow[b]{2}{*}{ I } & \multicolumn{4}{|c|}{$\mathrm{Bab}$} & \multicolumn{3}{|c|}{$\mathrm{Jm}$} \\
\hline & & & II & III & IV & $\mathrm{V}$ & VI & 1 & $\%$ \\
\hline \multirow{8}{*}{ Knowing } & Recall & 6 & 19 & 3 & 1 & 0 & 0 & 29 & 33,72 \\
\hline & Recognize & 2 & 4 & 0 & 0 & 0 & 0 & 6 & 6,98 \\
\hline & Compute & 0 & 19 & 1 & 0 & 0 & 0 & 20 & 23,26 \\
\hline & Retrieve & 8 & 0 & 1 & 0 & 0 & 1 & 10 & 11,63 \\
\hline & $\begin{array}{l}\text { Classify/orde } \\
r\end{array}$ & 7 & 14 & 0 & 0 & 0 & 0 & 21 & 24,42 \\
\hline & Measure & 0 & 0 & 0 & 0 & 0 & 0 & 1 & 0,00 \\
\hline & Jumlah & 23 & 56 & 56 & 1 & 0 & 1 & 86 & 100 \\
\hline & Determine & 18 & 15 & 9 & 14 & 2 & 9 & 66 & 38,29 \\
\hline \multirow{3}{*}{ Applying } & $\begin{array}{l}\text { Represent/ } \\
\text { Model }\end{array}$ & 18 & 8 & 7 & 7 & 0 & 9 & 49 & 28,00 \\
\hline & Implement & 1 & 17 & 6 & 23 & 12 & 0 & 59 & 33,71 \\
\hline & Jumlah & 37 & 40 & 22 & 43 & 14 & 18 & $\begin{array}{c}17 \\
4\end{array}$ & 100 \\
\hline \multirow{7}{*}{ Reasoning } & Analyze & 6 & 8 & 1 & 7 & 12 & 0 & 34 & 36,56 \\
\hline & $\begin{array}{l}\text { Integrated/ } \\
\text { Synthesize }\end{array}$ & 3 & 7 & 1 & 8 & 4 & 0 & 23 & 24,73 \\
\hline & Evaluate & 0 & 3 & 1 & 2 & 5 & 0 & 11 & 11,83 \\
\hline & $\begin{array}{l}\text { Draw } \\
\text { Conclusions }\end{array}$ & 0 & 0 & 1 & 0 & 0 & 4 & 5 & 5,38 \\
\hline & Generalize & 0 & 0 & 0 & 2 & 0 & 0 & 2 & 2,15 \\
\hline & Justify & 5 & 4 & 1 & 2 & 6 & 0 & 18 & 19,35 \\
\hline & Jumlah & 14 & 22 & 5 & 21 & 27 & 4 & 93 & 100 \\
\hline
\end{tabular}

Berdasarkan tabel 5, dapat diketahui bahwa soal-soal pada domain knowing, aspek kognitif yang lebih banyak termuat adalah recall yaitu sebanyak 33,72\% kemudian Classify/order $24,42 \%$, compute $23,26 \%$, retrieve $11,63 \%$ dan recognize $6,98 \%$. Adapun measure tidak termuat dalam soal pada domain knowing. Untuk soal-soal pada domain applying, aspek kognitif yang lebih banyak termuat yaitu determine 38,29\%, implement sekitar $33,71 \%$ dan represent/model sekitar 28,00\%. Adapun untuk soal-soal pada domain reasoning, aspek kognitif yang lebih banyak termuat adalah analyze sekitar 36,56\%, integrated/synthesize $24,73 \%$, justify $19.35 \%$, evaluate $11,83 \%$, draw conclusions $5,38 \%$ dan yang paling sedikit generalize yaitu sekitar 2,15\%.

Hasil penelitian ini senada dengan penelitian yang dilakukan oleh Etik Rahayu, Hardi Suyitno, dan Iwan Junaedi (2012) tentang analisis soal geometri dalam buku matematika bilingual untuk sekolah menengah pertama kelas VIII berdasarkan kriteria internasional TIMSS 2007 yang menyimpulkan bahwa proporsi aspek kognitif yang paling tinggi adalah recall dengan persentase $28,26 \%$ kemudian aspek compute dengan persentase $26,57 \%$; aspek SRP 10,85\%; aspek implement $10,65 \%$; aspek retrieve $8,36 \%$; aspek recognice $6,17 \%$; 
analyze 1,99\%; aspek measure 1,59\%; aspek generalize 1,09\%; aspek SNRP 1,00\%; aspek classify $0,80 \%$; aspek represent $0.80 \%$, aspek justify $0.80 \%$; aspek select $0.60 \%$; aspek model $0.30 \%$ dan aspek synthesize $0,20 \%$.

Menurut TIMSS 2015 assessment framework, proporsi kemampuan yang diuji pada dimensi kognitif untuk kelas VIII SMP mencapai 35\% untuk knowing (pengetahuan), 45\% untuk applying (penerapan) dan 25\% untuk reasoning (penalaran). Hal ini dapat disimpulkan bahwa buku siswa matematika kurikulum 2013 untuk kelas VIII semester I cakupan domain kognitifnya belum sesuai proporsi yang diuji pada dimensi kognitif dalam TIMSS, yang mana untuk domain applying dan reasoning justru melebihi proporsi yang diuji dalam TIMSS sedangkan domain knowing lebih sedikit dari proporsi yang diuji dalam TIMSS.

Penelitian ini juga senada dengan penelitian Qurotul Novida Barmoyo, Wasis (2014) tentang analisis soal-soal dalam BSE, UN dan TIMSS ditinjau dari domain kognitif dan indikator keterampilan berpikir kritis menyimpulkan bahwa ditinjau dari domain kognitif soal-soal BSE dominan pada aspek penerapan (applying) sebesar 48\%, soal UN dominan pada aspek pengetahuan (knowing) sebesar 35\% dan soal TIMSS dominan pada aspek penerapan (applying) sebesar 47\%.

Hasil penelitian yang serupa oleh Siti Lisakdiyah (2010) tentang analisis deskriptif pada soal-soal dalam Buku Sekolah Elektronik (BSE) matematika untuk SMP kelas VIII berdasarka kriteria TIMSS Video Study menyimpulkan bahwa dari 1137 soal yang dianalisis, sebanyak 640 soal (56\%) merupakan soal aljabar dan 497 soal (44\%) merupakan soal geometri. Berdasarkan tipe penyelesaian soal, diperoleh $63 \%$ soal-soal yang menggunakan prosedur, $18 \%$ untuk soal-soal yang menerapkan konsep dan $19 \%$ untu soal yang membuat hubungan. Ditinjau dari kompleksitas prosedural, 59\% soal memiliki tingkat procedural yng rendah. Soal-soal yang memiliki tingkat procedural menengah adalah sebesar 32\%, selanjutnya $9 \%$ untuk soal dengan tingkat prosedural tinggi. Proporsi soal latihan $63 \%$ dan $37 \%$ untuk soal aplikasi.

Sedangkan untuk menyelesaikan soal pada tingkat reasoning peserta didik dituntut menggunakan logika dan kemampuan berpikir sistematis termasuk menggunakan penalaran intuitif dan penalaran induktif yang berdasar pada pola-pola yang dapat digunakan untuk memecahkan masalah baru dan non familiar. Hal ini dikuatkan dengan penelitian oleh Georgius Rocki Agasi dan Andy Rudhito (2014) tentang kemampuan siswa kelas VIII dalam menyelesaikan soal-soal TIMSS tipe penalaran (reasoning) menyimpulkan bahwa kemampuan penalaran (reasoning) sangat diperlukan dalam pembelajaran matematika karena penalaran merupakan dasar dari matematika itu sendiri. Hasil penelitian ini menunjukkan $77 \%$ siswa mengalami kesulitan dalam mengerjakan soal-soal penalaran yang membutuhkan pemahaman lebih terhadap maksud soal.

Dalam penelitian ini, juga ditemukan adanya relevansi antara TIMSS 2015 Assessment Framework dengan domain kognitif Bloom revisi. Dalam domain knowing memuat aspek kognitif recall yang meliputi indikator mengingat definisi, mengingat terminologi, mengingat sifat-sifat bilangan, mengingat sifat-sifat geometri dan mengingat notasi. Hal ini relevan dengan proses mengingat dalam teori domain kognitif bloom revisi. Dalam teori domain kognitif Bloom revisi proses mengingat dikaitkan dengan mengambil pengetahuan yang dibutuhkan dalam memori jangka panjang, pengetahuan tersebut dapat meliputi pengetahuan faktual, konseptual, prosedural dan metakognitif atau kombinasi dari beberapa pengetahuan tersebut.

Adapun yang membedakan adalah proses mengingat dalam domain kognitif Bloom revisi juga merupakan padanan dari aspek kognitif retrieve (mengambil kembali), akan tetapi 
retrieve dalam TIMSS 2015 Assessment Framework memunyai definisi tersendiri yakni mendapatkan informasi dari soal yang berupa grafik, tabel atau sumber lain.

Domain knowing dalam TIMSS 2015 Assessment Framework diantaranya memuat aspek kognitif recall (mengingat kembali), recognize (mengenali), retrieve (mengambil kembali) dan classify/order (mengklasifikasikan). Dalam domain kognitif Bloom revisi, mengingat kembali (recall) dan mengenali (recognize) termasuk dalam proses kognitif dalam kategori mengingat (remember). Sedangkan classify/order termasuk dalam proses kognitif dalam kategori memahami (understand). Jadi domain kognitif knowing dalam TIMSS Assessment Framework secara tersirat merupakan cerminan dari tingkatan mengingat dan memahami dalam domain kognitif Bloom revisi.

Dalam domain kognitif applying TIMSS 2015 Assessment Framework, domain ini dihubungkan dengan kemampuan peserta didik untuk menerapkan pengetahuan yang meliputi fakta, konsep dan kemampuan matematis maupun pemahaman konsep untuk memecahkan masalah atau menjawab pertanyaan. salah satu aspek kognitif yang termuat adalah implement yang meliputi indikator mengimplementasikan strategi dan operasi untuk memecahkan masalah yang melibatkan konsep dan prosedur matematika yang familier. Dalam domain kognitif Bloom revisi juga terdapat proses mengaplikasikan (apply) yang melibatkan penggunaan prosedur-prosedur tertentu untuk menyelesaikan masalah dimana implement (mengimplementasikan) juga termasuk dalam proses kognitif dalam kategori mengaplikasikan (applying). Hal ini juga termasuk kesesuaian. Jadi domain kognitif applying dalam TIMSS 2015 Assessment Framework secara tersirat merupakan cerminan dari tingkatan mengaplikasikan (Apply) dalam domain kognitif Bloom revisi.

Dalam domain kognitif reasoning TIMSS 2015 Assesment Framework, memuat aspek kognitif diantaranya menganalisis (analyze), menyatukan/synthesis (integrated/synthesize), dan mengevaluasi (evaluate). Dalam domain kognitif Bloom revisi menganalisis dan mengevaluasi merupakan tingkatan proses kognitif keempat dan kelima. Adapun mencipta merupakan tingkatan proses kognitif keenam. Mencipta melibatkan proses menyusun elemenelemen menjadi sesuatu yang baru dan koheren. Hal ini sesuai dengan aspek kognitif menyatukan/menyintesis (integrated/synthesize) dalam TIMSS Assesment Framework, dimana (integrated/synthesize) meliputi indikator menghubungkan berbagai elemen pengetahuan yang berbeda, representasi yang terkait dan prosedur untuk menyelesaikan masalah. Jadi domain kognitif reasoning dalam TIMSS 2015 Assessment Framework secara tersirat merupakan cerminan dari tingkatan menganalisis, mengevaluasi dan mencipta dalam domain kognitif Bloom revisi.

Hasil penelitian ini didukung dengan penelitian Puji Wibowo (2016) tentang analisis tingkat kognitif latihan soal berdasarkan taksonomi bloom pada buku teks matematika SMP kelas VIII kurikulum 2013 menyimpulkan bahwa soal pada buku teks matematika SMP kelas VIII kurikulum 2013 semester 1 tersebar dalam tingkat proses kognitif mengingat (C1) sebanyak $6(9,68 \%)$ butir soal, memahami (C2) sebanyak $27(43,55 \%)$ butir soal, menerapkan (C3) sebanyak $24(38,71 \%)$ butir soal, menganalisis (C4) sebanyak $3(4,84 \%)$ butir soal, mengevaluasi (C5) sebanyak $2(3,23 \%)$ butir soal, dan menciptakan (C6) sebanyak $0(0 \%)$ butir soal. Dari data tersebut memahami (C2) dan menerapkan (C3) merupakan tingkat proses kognitif yang paling banyak digunakan. Soal pada buku teks matematika SMP kelas VIII kurikulum 2013 semester 1 lebih menekankan bagaimana suatu teknik, metode atau langkahlangkah atau prosedur dalam menyelesaikan suatu permasalahan matematika. Hal ini sesuai dengan banyaknya tingkat proses kognitif memahami dan menerapkan yang terdapat pada soal yang cenderung menggunakan tingkat pengetahuan prosedural untuk menyelesaikan soalsoal tersebut. 
Meskipun terdapat beberapa kesesuaian dan ketidaksesuaian ataupun perbedaan antara TIMSS 2015 Assessment Framework dan domain kognitif Bloom revisi, secara keseluruhan TIMSS 2015 Assessment Framework merupakan refleksi dari taksonomi domain kognitif Bloom revisi. Dimana TIMSS 2015 Assessment Framework mencoba memperjelas taksonomi domain kognitif dari Bloom dalam bahasa dan konteks matematika. Soal berikut menunjukkan relevansi antara TIMSS 2015 Assessment Framework dan domain kognitif Bloom revisi:

2. Suatu ketika Jodi dan Nikolas diminta menentukan apakah $8-17-15$ adalah suatu Tripel Pythagoras. Kemudian mereka menjawab:
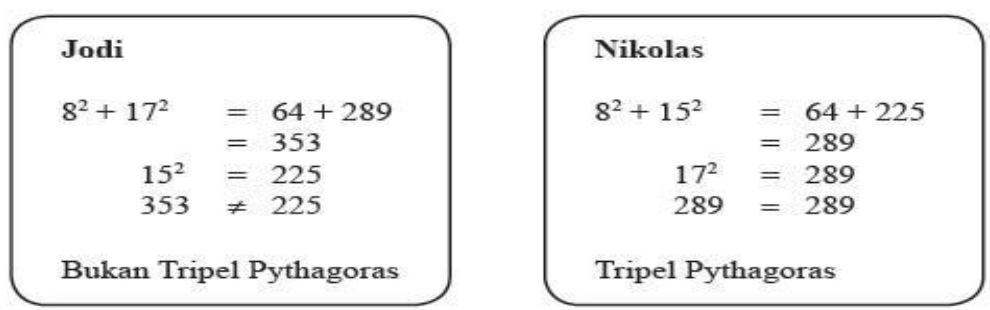

Soakahdiatasbemengakåkan peserta didik untuk mengingat dan memahami konsep mengenai teorema phytagoras. Selanjutnya mengaplikasikan teorema tersebut dalam penyelesaian soal. Selain itu peserta didik diminta untuk membandingkan dua jawaban yang ada kemudian mengidentifikasi jawaban yang benar beserta alasan yang tepat. Hasil penelitian menunjukkan bahwa berdasarkan TIMSS 2015 assessment framework, soal diatas memuat aspek kognitif evaluate karena memuat indikator, "mengevaluasi strategi dan solusi alternatif untuk menyelesaikan masalah", dan memuat aspek kognitif justify karena memuat indikator memberikan argumen matematis yang mendukung strategi/solusi. Sehingga soal diatas termasuk dalam tingkatan soal reasoning. Soal di atas apabila dianalisis berdasarkan domain kognitif Bloom revisi, soal tersebut termasuk dalam tingkatan mengevaluasi (evaluate) karena memuat indikator "mengambil keputusan berdasarkan kriteria dan atau standar."

Analisis tambahan dalam penelitian ini, adalah adanya kesalahan penyajian soal ataupun soal yang dinilai kurang valid dalam buku ini. Soal-soal tersebut adalah:

\section{Soal no.4 latihan 3.1}

4. Diketahui $K=\{p, q\}$ dan $L=\{2,3,4\}$

a. Buatlah semua pasangan berurutan dari himpunan $A$ ke himpunan $B$ yang membentuk fungsi

b. Tentukan banyaknya fungsi yang mungkin dari himpunan $A$ ke himpunan $B$.

Pada soal di atas, himpunan yang diketahui adalah himpunan dan himpunan. Namun, perintah/pertanyaan yang diajukan pada poin a dan $b$ menggunakan himpunan $\mathrm{A}$ dan himpunan $\mathrm{B}$, bukan himpunan $\mathrm{K}$ dan himpunan $\mathrm{L}$.

\section{Soal no.2 Uji kompetensi 4:}

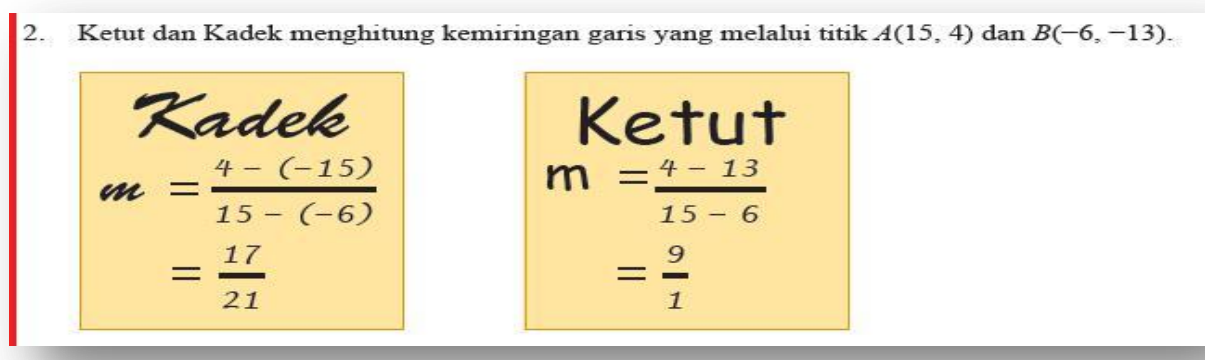


Dapat dilihat bahwa soal diatas belum lengkap, yaitu tidak ada instruksi yang harus dilakukan. Seharusnya ada pernyataan "Perhitungan siapakah yang benar?"

\section{Soal no.3 latihan 6.2}

3. Data jenis pekerjaan siswa kelas VIII disajikan dalam tabel sebagai berikut.

\begin{tabular}{|l|l|c|}
\hline No & Jenis Pekerjaan & Banyak orang tua \\
\hline 1 & Pegawai Negeri & 35 \\
\hline 2 & Pegawai BUMN & 15 \\
\hline 3 & TNI/POLRI & 10 \\
\hline 4 & Pegawai swasta & 20 \\
\hline 5 & Pedagang & 25 \\
\hline 6 & Petani & 40 \\
\hline 7 & Lain-lain & 45 \\
\hline
\end{tabular}

Soal diatas hanya diketahui sebuah data mengenai jenis pekerjaan orang tua siswa, tidak ada perintah/ pertanyaan yang diajukan dalam soal. Sehingga soal tersebut dikategorikan soal yang salah atau kurang valid.

Secara keseluruhan dari semua soal latihan dan soal uji kompetensi tiap bab yang terdapat pada buku siswa matematika kurikulum 2013 kelas VIII semester I terbitan Kemendikbud, terdapat 3 soal yang mempunyai kesalahan penyajian maupun soal yang dinilai salah atau kurang valid, sehingga soal tersebut tidak memuat domain maupun aspek kognitif.

\section{SIMPULAN}

Berdasarkan hasil penelitian yang diperoleh, maka dapat disimpulkan bahwa analisis terhadap materi dan butir-butir soal dalam buku siswa matematika kurikulum 2013 Kelas VIII Semester I terbitan Kemendikbud berdasarkan dimensi konten dan dimensi kognitif dari TIMSS 2015 Assessment framework sebagai berikut:

Berdasarkan analisis penyajian materi ditinjau dari proporsi masing-masing domain konten, domain aljabar menempati proporsi tertinggi dengan persentase 50\%, domain geometri dengan persentase $33,33 \%$ sedangkan domain data dan peluang dengan persentase $16,67 \%$ serta tidak terdapat materi yang termasuk dalam domain bilangan.

Penyajian materi ditinjau dari dimensi kognitif, paling besar merupakan domain applying $(68,42 \%)$ kemudian knowing $(21,05 \%)$ sedangkan domain reasoning mempunyai persentase yang paling rendah yaitu $10,53 \%$.

Untuk analisis penyajian soal-soal latihan ditinjau dari proporsi dimensi konten, soal latihan yang tentang aljabar mempunyai persentase $60,64 \%$, soal latihan tentang materi geometri mempunyai persetase $32,13 \%$ sedangkan soal latihan tentang materi data dan peluang mempunyai persentase sebesar $7,23 \%$.

Ditinjau dari dimensi kognitif untuk soal-soal latihannya, dari 212 soal yang dianalisis diperoleh 36 soal hanya mencapai tingkat kognitif pada domain knowing dengan persentase $16,98 \%, 114$ soal sudah mencapai tingkat kognitif pada domain applying dengan persentase 
$53,77 \%$ dan 62 soal sudah mencapai tingkat kognitif pada domain reasoning dengan persentase $29,25 \%$.

Ditinjau dari aspek-aspek kognitifnya, soal-soal pada domain knowing, aspek kognitif yang termuat adalah recall $33,72 \%$, classify/order $24,42 \%$, compute $23,26 \%$, retrieve $11,63 \%$ dan recognize 6,98\%.

Untuk soal-soal pada domain applying, aspek kognitif yang termuat yaitu determine $37,93 \%$, implement $33,91 \%$ dan represent/model $28,16 \%$.

Adapun untuk soal-soal pada domain reasoning, aspek kognitif yang termuat adalah analyze $36,56 \%$, integrated/synthesize $24,73 \%$, justify $19,35 \%$, evaluate $11,83 \%$, draw conclusions $5,38 \%$ dan generalize $2,15 \%$.

Pada buku siswa matematika kurikulum 2013 kelas VIII semester 1 terbitan Kemendikbud cakupan domain konten dan domain kognitifnya belum sesuai proporsi yang diuji pada dimensi konten dan dimensi kognitif dalam TIMSS. Akan tetapi, materi dan soalsoal dalam buku siswa matematika kurikulum 2013 untuk kelas VIII semester I ini sudah memberikan bekal untuk melatih dan mendorong tingkat perkembangan berpikir peserta didik. Domain bilangan tidak terdapat dalam buku siswa dan soal-soal yang dianalisis juga masih terdapat soal-soal yang salah penyajian maupun kurang valid. Oleh karena itu, buku ini masih perlu diadakan perbaikan.

\section{DAFTAR PUSTAKA}

Agasi, G. R \& Rudhito, M. A. 2014. Kemampuan Siswa Kelas VIII Dalam Menyelesaikan Soal-soal TIMSS Tipe Penalaran. Vol : 5, No. 1. ISSN : 2087-0922 : 879-888.

Darhim. 1993. Workshop Matematika. Jakarta: Depdikbbud Direktorat Jenderal Paendidikan Dasar dan Menengah: Bagian Proyek Penataran Guru SLTP Setara D-III.

Rahayu E., Suyitno H., Junaedi I. 2012. Analisis Deskriptif Soal Geometri dalam Buku Matematika Bilingual untuk Sekolah Menengah Pertama Kelas VIII Berdasarkan Kriteria International Assessment TIMSS 2007. Jurnal Kreano, 3(1):1 - 15.

Kemdikbud. 2014. Matematika SMP/MTs Kelas VIII Semester 1 Edisi Revisi. Jakarta: Kemdikbud.

Lisakdiyah, Siti. 2010. Analisis Deskriptif pada Soal-Soal dalam Buku Sekolah Elektronik (BSE) Matematika untuk Sekolah Menengah Pertama Kelas VIII Berdasarkan Kriteria TIMSS Video Study. Skripsi, Jurusan Matematika, Fakultas Matematika dan Ilmu Pengetahuan Alam, Universitas Negeri Semarang.

Mahanani, G. L. 2016. Kemampuan Pemecahan Masalah Matematika Aljabar Berbasis TIMSS Pada Siswa SMP Kelas VIII . Skripsi, tidak dipublikasikan, UMS, Surakarta, Indonesia. 
Mullis, I.V.S., Martin, M.O., Foy, P., \& Arora, A. 2012. TIMSS 2011 Internastional Result in Mathematics. Chestnut Hill, MA: TIMSS \& PIRLS International Study Center, Boston College.

Mullis, I.V.S. \& Martin, M.O. (ed.). 2013. TIMSS 2015 Mathematics Framework Chestnut Hill, MA: TIMSS \& PIRLS International Study.

Qurotul Novida Barmoyo, Wasis. 2014. Analisis Soal-soal dalam Buku BSE (Buku Sekolah Elektronik), UN (Ujian Nasional) dan TIMSS (Trends in International Mathematics and Science Study) Ditinjau dari Doain Kognitif dan Indikator Keterampilan Berpikir Kritis. Jurnal Inovasi Pendidikan Fisika (JIPF). ISSN: 2302=4496. Vol. 03, No. 01: 8-14

Rista, A., Zulkardi \& Hartono, Y. 2013. Pengembangan Soal Penalaran Model TIMSS Matematika SMP. Jurnal Penelitian dan Evaluasi Pendidikan No. 2: 230-240.

Wibowo, Puji. 2015. Analisis Tingkat Kognitif Latihan Soal Berdasarkan Taksonomi Bloom Pada Buku Teks Matematika SMP Kelas VIII Kurikiulum 2013. Skripsi tidak dipublikasikan, Universitas Jember. 